\title{
DESAIN SISTEM INFORMASI GEOGRAFIS PEMETAAN GIZI BURUK DI KOTA SEMARANG
}

\author{
Bambang Agus Herlambang ${ }^{1}$ \\ Program Studi Informatika Fakultas Teknik \\ Universitas PGRI \\ Semarang
}

\author{
Vilda Ana Veria Setyawati ${ }^{2}$ \\ Program Studi Kesehatan Masyarakat Fakultas \\ Kesehatan Universitas Dian Nuswantoro \\ Semarang
}

\begin{abstract}
Severe Protein Energy Malnutrition (PEM) are four major problems in the nutrition world. Such as iodine deficiency disorders, and lack of vitamin A. It also often called malnutrition caused by shortages associated poor dietary intake in terms of quality and quantity. Based on data from Semarang Health Office in 2013, the scope of severe PEM in children under five with BGM (Down Red Lines) of 1,502 (1.7\%) and children with severe malnutrition by $32(0.04 \%)$. The number of infants with BGM (Down Red Lines) in Semarang in 2013 was 1,502 or 1.7\%. Geographical Information Systems (GIS) is one of the information technology that was designed to use spatial and non spatial data. The system could report information and summarize the malnutrition data thus help to process analysis of the causes of malnutrition in the region. Geographic information systems development method used waterfall method with Unified Modeling tools laguage (UML). System testing was done by white box method for testing complexity groove siklomatis on system design and black box to test the input and output.
\end{abstract}

Keywords - Design, Geographic Information Systems, Severe Protein Energy Malnutrition, Semarang

\section{PENDAHULUAN}

Keberhasilan pembangunan suatu bangsa berhubungan erat dengan pembangunan sumber daya manusia. Sumber daya yang dibutuhkan tidak hanya dari segi kuantitas tetapi juga dari kualitas. Salah satu yang menentukkan kualitas sumber daya manusia adalah kesehatan yang ditandai dengan beberapa parameter yaitu rendahnya angka kematian balita. Beberapa hal menjadi penyebab kematian balita mulai dari kekurangan gizi dan menderita suatu penyakit. Kekurangan gizi merupakan empat masalah besar di bidang gizi selain anemia, gangguan kekurangan yodium, dan kekurangan vitamin A. Gizi buruk juga sering disebut malnutrisi yang berhubungan disebabkan oleh kekurangan asupan makanan yang buruk dari segi kualitas dan kuantitas.

Program gizi yang sudah dilaksanakan pada dasarnya mampu menurunkan angka kejadian gizi kurang dan gizi buruk pada balita belum mencapai target yang diharapkan dalam Rencana Pembangunan Jangka Menengah Nasional tahun 2010-2014, yaitu 15\% dan Millenium Develpoment Goals (MDGs) tahun 2015, yaitu 15,5\% bahkan di beberapa daerah prevalensinya diatas angka nasional. Data Riset Kesehatan Dasar (RisKesDas) menunjukkan prevalensi gizi kurang pada balita tahun 2010 adalah $17,9 \%$ turun dari $18,4 \%$ tahun 2007. Kondisi gizi kurang dan buruk ini menyebabkan risiko balita menderita penyakit infeksi meningkat karena daya tahan tubuh yang rendah.Bahkan kondisi ini dapat menyebabkan kematian. WHO menyatakan kematian balita di negara berkembang 60\%-nya disebabkan gizi buruk.

Berdasarkan data Dinas Kesehatan Kota Semarang 2013, cakupan gizi buruk balita dengan BGM ( Bawah Garis Merah ) sebanyak 1.502 (1,7\%) dan balita dengan gizi buruk sebanyak $32(0,04 \%)$. Cakupan balita yang berat badannya naik di kota Semarang tahun 2013 belum mencapai target yang telah ditetapkan di dalam Standar Pelayanan Minimal Propinsi Jawa Tengah sebesar 80\%. BGM (Bawah Garis Merah) merupakan hasil penimbangan dimana berat badan balita berada dibawah garis merah pada KMS. Jumlah balita dengan BGM (Bawah Garis Merah) di Kota Semarang tahun 2013 adalah 1.502 atau $1,7 \%$. [1]

Perkembangan teknologi untuk peningkatan kualitas kesehatan banyak dimanfaatkan di beberapa wilayah secara global. Kota Semarang merupakan salah satu kota memiliki literasi tinggi terhadap kemajuan teknologi. Namun, penggunaan sistem informasi geografis masih jarang ditemukan. Bebapa hal melatar belakangi penggunaan sistem informasi geografi ini. Prevalensi penyakit berhubungan dengan aspek lingkungan/ geografi/spasial/keruangan. Sehingga perlu dibuat sebuah sistem informasi yang dapat melaporkan dan merangkum data-data yang ada sehingga membantu untuk proses analisis penyebab gizi buruk di suatu wilayah.

\section{a. SIG (Sistem Informasi Geografis)}

Sistem Informasi Geografi (SIG) atau Geographic Information System (GIS) merupakan salah satu teknologi informasi yang dirancang untuk bekerja dengan data yang bereferensi spasial atau berkoordinat geografi atau dengan kata lain sistem 
basis data dengan kemampuan khusus untuk menangani data yang bereferensi keruangan (spasial) bersamaan dengan seperangkat operasi kerja. Bentuk produk suatu SIG dapat bervariasi baik dalam hal kualitas, keakuratan dan kemudahan pemakainya. Hasil ini dapat dibuat dalam bentuk peta-peta, tabel angka-angka: teks di atas kertas atau media lain (hard copy), atau dalam cetak lunak (seperti file elektronik). [2]

\section{b. GIZI BURUK}

Gizi buruk merupakan istilah teknis yang biasanya digunakan oleh kalangan gizi, kesehatan dan kedokteran.Gizi buruk adalah kondisi seseorang yang nutrisinya di bawah rata-rata. Hal ini merupakan suatu bentuk terparah dari proses terjadinya kekurangan gizi menahun. [3]

\section{DIAGRAM PERENCANAAN SIG}

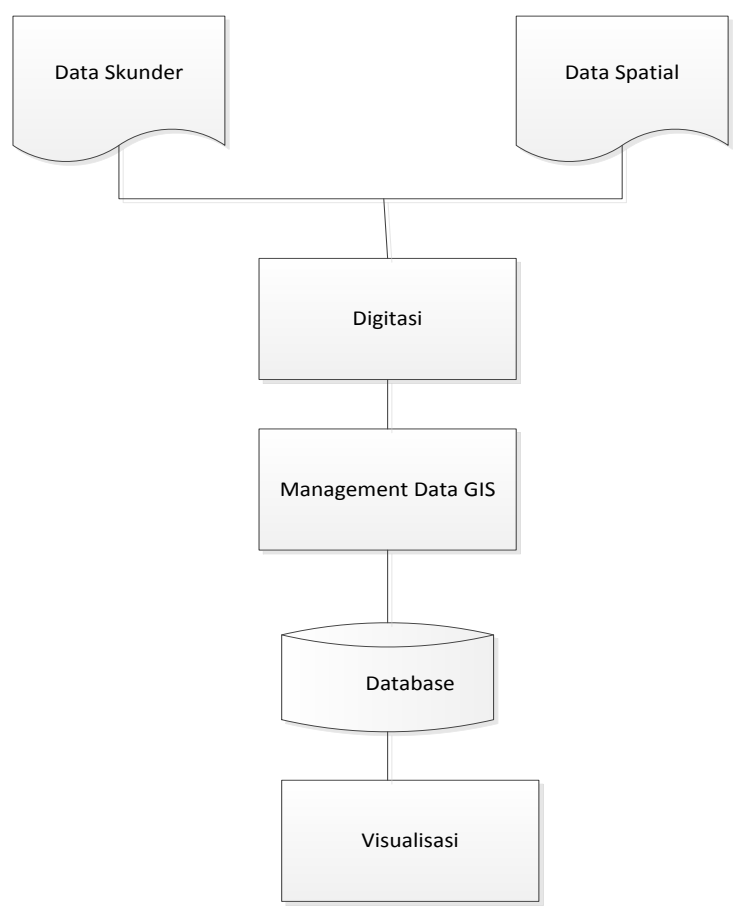

Gambar 1 : Diagram Perencanaan SIG

\section{METODE PENGEMBANGAN SISTEM}

Metode pengembangan sistem yang digunakan dalam penelitian ini adalah metode waterfall. Metode ini mengusulkan pendekatan pengembangan perangkat lunak yang sistematik dan sekuensial, metode ini didasarkan pada beberapa aktifitas berikut :

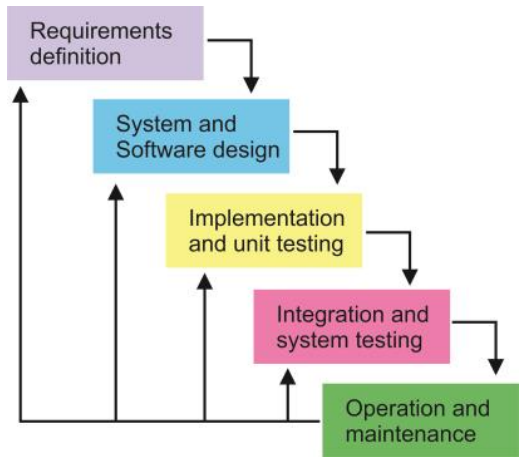

Gambar 2 : Metode Waterfall

\section{HASIL DAN PEMBAHASAN}

\section{Analisis Kebutuhan}

Analisa kebutuhan dilakukan untuk mengidentifikasi permasalahan yang terdapat pada sistem yang dibangun meliputi perangkat keras (hardware), perangkat lunak (software) dan pengguna (user). Analisis system sangat diperlukan sebagai awal bagi tahap perancangan sistem yang akan dibangun. Adapun analisis Sistem informasi geografis pemetaan gizi buruk di kota semarang yang dilakukan antara lain: identifikasi permasalahan, spesifikasi system, spesifikasi pengguna, lingkungan operasi, Kebutuhan Perangkat Keras dan Perangkat Lunak, Identifikasi Kebutuhan Sumber Daya Manusia dan Pemilikan Kelayakan Sistem.

\section{a. Identifikasi Masalah}

Kota Semarang dengan luas wilayah 373,70 $\mathrm{Km} 2$. Secara administratif Kota Semarang terbagi menjadi 16 Kecamatan dan 177 Kelurahan. Data Dinas Kesehatan Kota Semarang 2013 menunjukkan cakupan gizi buruk balita dengan BGM ( Bawah Garis Merah ) sebanyak $1.502(1,7 \%)$ dan balita dengan gizi buruk sebanyak $32(0,04 \%)$ namun penyajian informasi dengan sistem informasi geografis masih jarang ditemukan. Berdasarkan permasalahan yang ada maka solusi yang dapat dilakukan adalah membuat desain suatu sistem informasi geografis yang berbasis website yang dapat menampilkan peta wilayah Kota Semarang, memetakan penderita gizi buruk dan memproses data spasial maupun data atribut dari hasil sensus penderita sehingga dapat menyajikan informasi penderita gizi buruk untuk masing-masing kecamatan yang ada dalam wilayah kota Semarang.

\section{b. Spesifikasi Aplikasi}

Sistem informasi geografis pemetaan gizi buruk yang akan dibangun memiliki kemampuan dan fungsi sebagai berikut :

1. Menampilkan peta wilayah kota semarang.

2. Menampilkan titik-titik koordinat peta yang meliputi latitude dan longitude.

3. Menyediakan tombol-tombol navigasi yang berfungsi untuk mengolah tampilan peta yaitu 
zoom, zoom in, zoom out, full extent identify dan show label.

4. Menampilkan data atribut kecamatan yang meliputi id kecamatan, nama kecamatan dan luas.

5. Menampilkan data atribut penderita yang meliputi id penderita, nama, jenis kelamin.

6. Menyediakan menu tambah, edit dan hapus untuk mengolah data atribut penderita gizi buruk.

7. Menampilkan laporan informasi data hasil sensus penderita gizi buruk.

8. User Friendly (desain antar muka yang mudah digunakan).

\section{c. Spesifikasi Pengguna}

Sistem Aplikasi untuk membantu pihak terkait dalam memetakan penderita gizi buruk dan memproses data tersebut sehingga dapat menyajikan informasi lengkap dengan menunjukkan lokasi wilayah kecamatan pada peta.

\section{d. Lingkungan Operasi}

Lingkungan operasi yang dibutuhkan dalam membangun aplikasi Sistem informasi geografis rehabilitasi hutan adalah sebagai berikut :

1. Sistem Operasi Microsoft Windows 7

Sistem operasi ini mendukung kinerja sistem informasi geografis pemetaan gizi buruk yang akan dibangun.

2. Web GIS

Untuk melakukan pembuatan web gis hal yang pertama dilakukan setelah proses digitasi adalah melakukan import database dari data shp ke dalam postgreSql yang nantinya digunakan sebagai database untuk mendukung pembuatan website GiS. Setelah database dalam postgreSql telah dibuat maka selanjutnya dilakukan konfigurasi dalam file .map dengan bantuan framework pmapper untuk menampilkan peta.

\section{e. Kebutuhan Perangkat Keras (Hardware)}

Perangkat keras yang digunakan dalam pembuatan GIS ini memerlukan spesifikasi khusus yang harus dipenuhi. Hal ini bertujuan agar system aplikasi yang dihasilkan dapat dipresentasikan dengan maksimal. Selain itu spesifikasi ini akan berpengaruh terhadap kinerja software aplikasi yang akan digunakan. Spesifikasi hardware yang digunakan untuk pembuatan system aplikasi ini, adalah hardware dengan dukungan untuk pengolahan database berbasis GIS.
f. Identifikasi Kebutuhan Sumber Daya Manusia

Agar sistem dapat berjalan secara optimal sesuai dengan yang diharapkan maka ada beberapa bagian yang harus dipegang oleh orang-orang yang memiliki keahlian sesuai dengan posisi masingmasing. Bagian-bagian yang dibutuhkan diantaranya

a. Analisa dan perancangan sistem. Bagian ini ditempati sumber daya manusia yang mampu dan menguasai analisa dan perancangan dalam pembuatan sistem aplikasi database yang berbasis GIS.

b. Programmer GIS adalah sumber daya manusia yang mampu dan menguasai dalam rancang bangun program database yang berbasiskan GIS

c. Operator Jaringan

Operator jaringan adalah sumber daya manusia yang dapat menghidupkan dan mengelola jaringan baik pada server maupun client yang dibutuhkan untuk proses on line .

d. Operator Komputer

Untuk operator komputer adalah sumber daya manusia yang dapat mengoperasikan komputer.

\section{Desain Sistem}

Dalam desain sistem ini, digunakan salah satu bahasa pemodelan yaitu UML. Bahasa pemodelan ini terdiri atas beberapa diagram, yaitu diagram usecase, diagram kelas, diagram interaksi, diagram keadaan, diagram aktivitas, dan diagram fisik. [4]

\section{a. Diagram Use-Case}

Diagram Use-Case yang digunakan dalam perancangan perangkat lunak penelitian ini ditunjukkan oleh Gambar berikut:

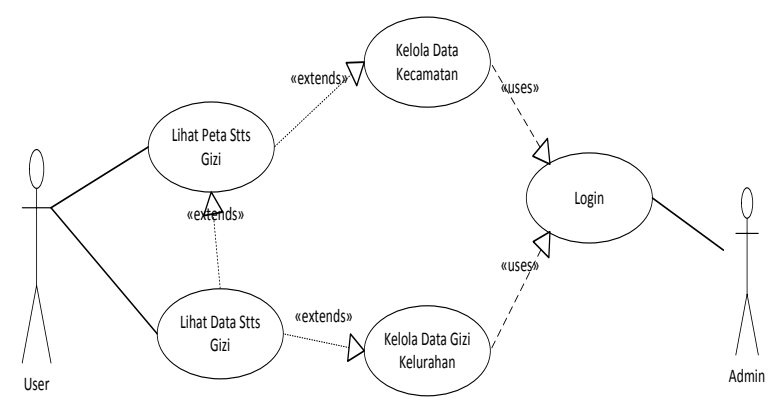

Gambar 3 : Diagram Use-Case

Sebagaimana yang terlihat dalam diatas terdapat 2 (dua) aktor dalam sistem aplikasi GIS pemetaan gizi buruk di kota Semarang. Aktor tersebut yaitu Admin yang dapat mengelola data kecamatan dan data penderita gizi buruk, sedangkan aktor user hanya dapat melihat peta status gizi dan data status gizi. Adapun skenario utama dan alternatif dari use case sebagai berikut:

$\begin{array}{ccc}\text { Skenario Use Case Login Admin } \\ \text { Nama Use Case } & : & \text { Login } \\ \text { Actor } & : & \text { Admin }\end{array}$


: Memasukkan user name dan password.

Tabel 1. Skenario Use Case Login Admin

\begin{tabular}{|c|c|}
\hline Actor & Sistem \\
\hline \multicolumn{2}{|l|}{ Skenario Normal } \\
\hline \multicolumn{2}{|l|}{$\begin{array}{l}\text { 1. Memasukkan } \\
\text { username }\end{array}$} \\
\hline & $\begin{array}{ll}\text { 2. } & \text { Memeriksa } \\
\text { tidaknya } & \text { valid } \\
\text { masukan } & \text { data }\end{array}$ \\
\hline & $\begin{array}{l}\text { 3. Masuk ke menu } \\
\text { utama aplikasi }\end{array}$ \\
\hline \multicolumn{2}{|l|}{ Skenario Alternatif } \\
\hline \multirow[t]{3}{*}{$\begin{array}{l}\text { 1. Memasukkan } \\
\text { username }\end{array}$} & \\
\hline & 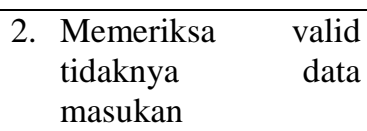 \\
\hline & $\begin{array}{l}\text { 3. Menampilkan pesan } \\
\text { login tidak valid }\end{array}$ \\
\hline \multirow[t]{3}{*}{$\begin{array}{l}\text { 4. Memasukkan } \\
\text { username dan } \\
\text { password yang } \\
\text { valid }\end{array}$} & \\
\hline & $\begin{array}{ll}\text { 5. } & \text { Memeriksa } \\
\text { tidaknya } & \text { valid } \\
\text { masukan } & \text { data } \\
\end{array}$ \\
\hline & $\begin{array}{l}\text { 6. Masuk ke menu } \\
\text { utama aplikasi }\end{array}$ \\
\hline
\end{tabular}

Skenario Use Case Pengelolaan Data Kecamatan

Nama Use : Kelola Data Kecamatan

Case

Actor : Admin

Skenario : Mengelola

Data

Kecamatan.

Tabel 2. Skenario Use Case Login Admin

\begin{tabular}{|c|c|}
\hline Actor & Sistem \\
\hline \multicolumn{2}{|l|}{ Skenario Normal } \\
\hline \multirow[t]{4}{*}{$\begin{array}{l}\text { 1. Memasukkan } \\
\text { data } \\
\text { kecamatan } \\
\text { sesuai kolom } \\
\text { yang ada }\end{array}$} & \\
\hline & $\begin{array}{l}\text { 2. Memeriksa valid } \\
\text { tidaknya data masukan }\end{array}$ \\
\hline & $\begin{array}{l}\text { 3. Menyimpan data } \\
\text { kecamatan ke database }\end{array}$ \\
\hline & $\begin{array}{ll}\text { 4. Manampilkan } & \text { pesan } \\
\text { sukses disimpan } & \\
\end{array}$ \\
\hline \multicolumn{2}{|l|}{ Skenario Alternatif } \\
\hline $\begin{array}{l}\text { 1. Memasukkan } \\
\text { data } \\
\text { kecamatan } \\
\text { sesuai kolom } \\
\text { yang ada }\end{array}$ & \\
\hline & $\begin{array}{l}\text { 2. Memeriksa valid } \\
\text { tidaknya data masukan }\end{array}$ \\
\hline
\end{tabular}

\begin{tabular}{|l|l|}
\hline & $\begin{array}{l}\text { 3. Menampilkan pesan data } \\
\text { tidak valid }\end{array}$ \\
\hline $\begin{array}{l}\text { 4. Memperbaiki } \\
\text { data masukan } \\
\text { yang tidak } \\
\text { valid }\end{array}$ & \\
\hline & $\begin{array}{l}\text { 5. Memeriksa valid } \\
\text { tidaknya data masukan }\end{array}$ \\
\hline & $\begin{array}{l}\text { 6. Menyimpan data } \\
\text { kecamatan ke basis data }\end{array}$ \\
\hline & $\begin{array}{l}\text { 7. Manampilkan pesan } \\
\text { sukses disimpan }\end{array}$ \\
\hline
\end{tabular}

Skenario Use Case Pengelolaan Data Gizi Balita

Nama Use Case : Kelola Data Gizi

Kelurahan

Actor : Admin

Skenario : Mengelola Gizi Kelurahan

Tabel 3. Skenario Use Case Gizi Kelurahan

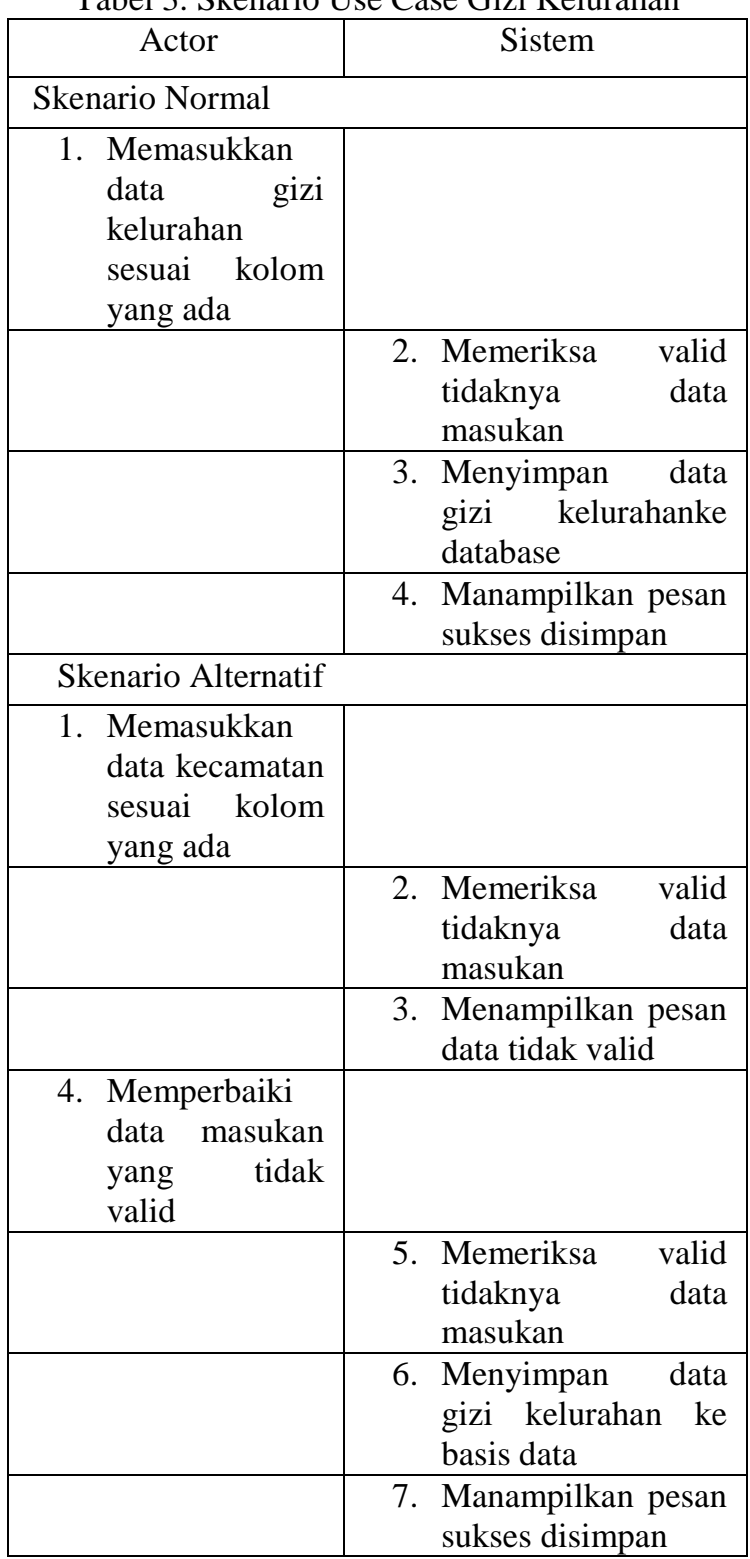

\section{Skenario Use Case Melihat Peta Status Gizi}

Nama Use Case : Melihat Peta Status Gizi 
Actor

: User

Skenario

: Melihat Peta Status Gizi

Tabel 4. Skenario Use Case Melihat Peta Status Gizi

\begin{tabular}{|c|c|}
\hline Actor & Sistem \\
\hline Skenario Normal \\
\hline $\begin{array}{l}\text { 1. Memilih nama/ } \\
\text { kode kecamatan }\end{array}$ & \\
\hline & $\begin{array}{l}\text { 2. Menampilkan } \\
\text { peta }\end{array}$ \\
\hline
\end{tabular}

Skenario Use Case Melihat Data Status Gizi Nama Use Case : Melihat Data Status Gizi Actor : User

Skenario $\quad$ : Melihat Data Status Gizi

Tabel 5. Skenario Use Case Melihat Data Status Gizi

\begin{tabular}{|c|c|}
\hline Actor & Sistem \\
\hline \multicolumn{2}{|l|}{ Skenario Normal } \\
\hline $\begin{array}{l}\text { 1. Memilih nama/ kode } \\
\text { kecamatan }\end{array}$ & \\
\hline & $\begin{array}{l}\text { 2. Menampilkan } \\
\text { Data Status } \\
\text { Gizi Kelurahan }\end{array}$ \\
\hline
\end{tabular}

\section{b. Activity Diagrams}

Activity Diagrams yang digunakan dalam perancangan perangkat lunak penelitian ini ditunjukkan oleh Gambar berikut:

1. Activity Diagram Login

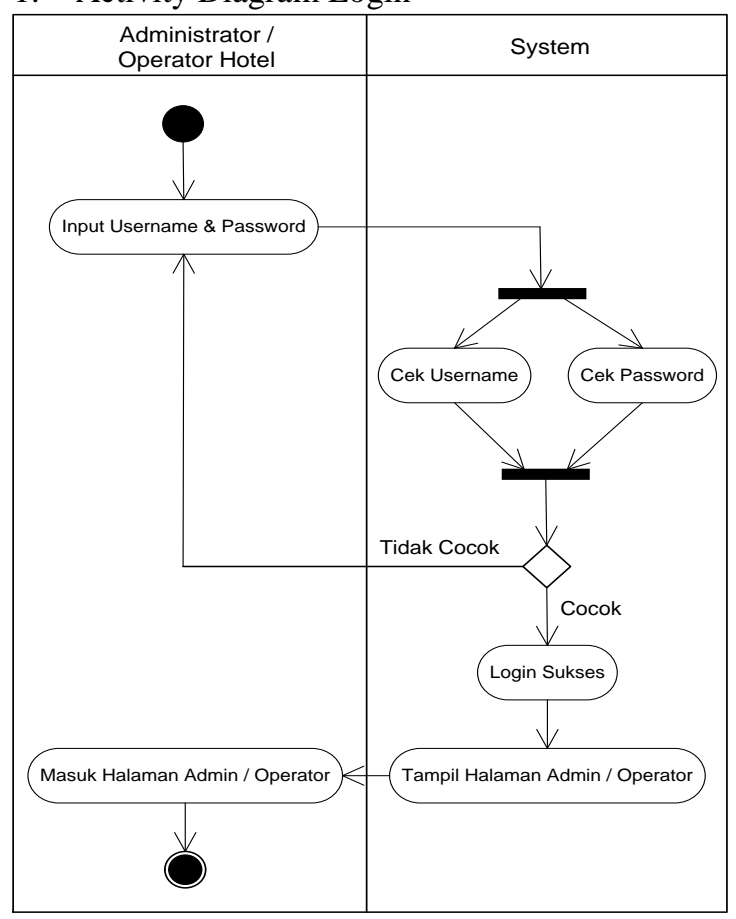

Gambar 4 : Activity Diagram Login
2. Activity Diagram Pengelolaan Data Kecamatan

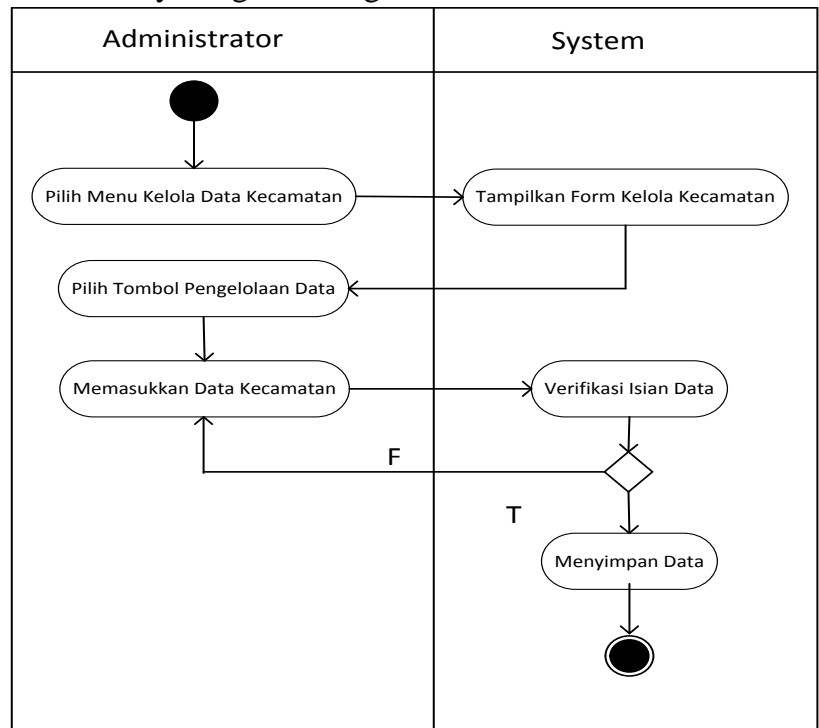

Gambar 5 : Activity Pengelolaan Data Kecamatan

3. Activity Diagram Pengelolaan Data Gizi Kelurahan

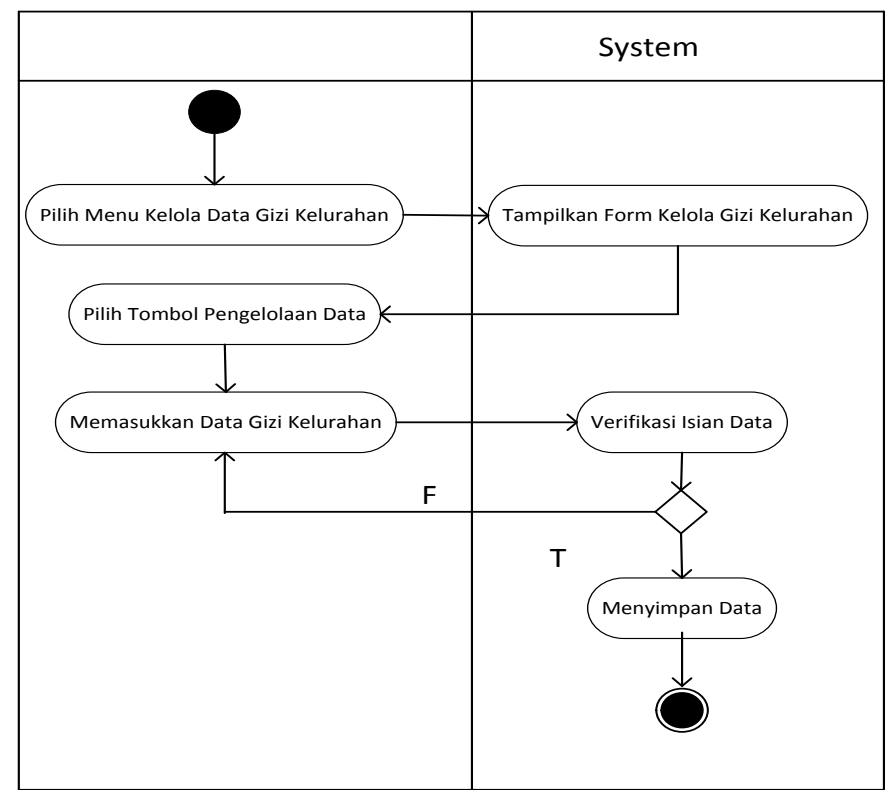

Gambar 6 : Activity Diagram Pengelolaan Gizi Kelurahan

4. Activity Diagram Melihat Peta Status Gizi 


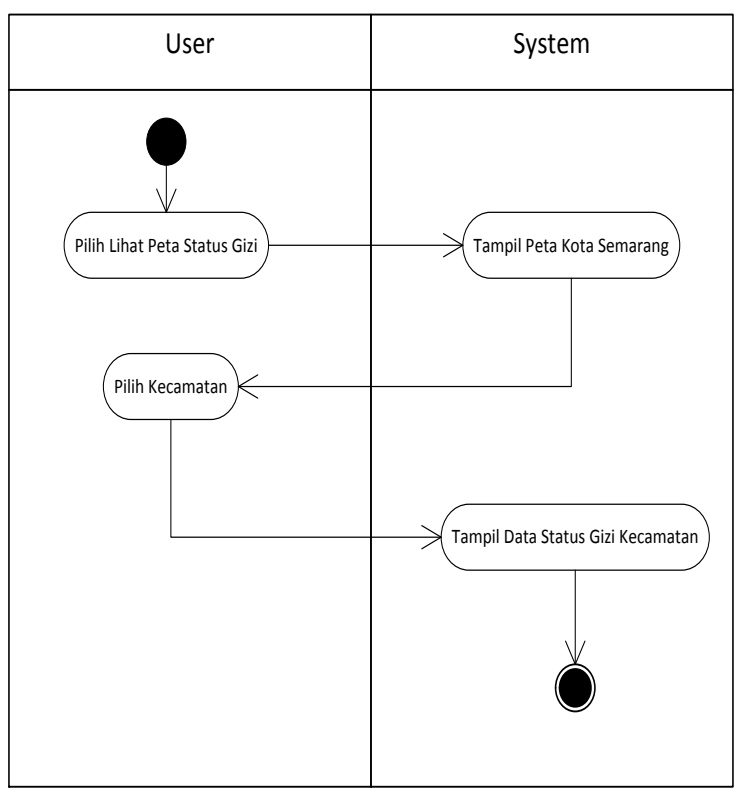

Gambar 7 : Activity Diagram Melihat Peta Status Gizi

5. Activity Diagram Melihat Data Status Gizi

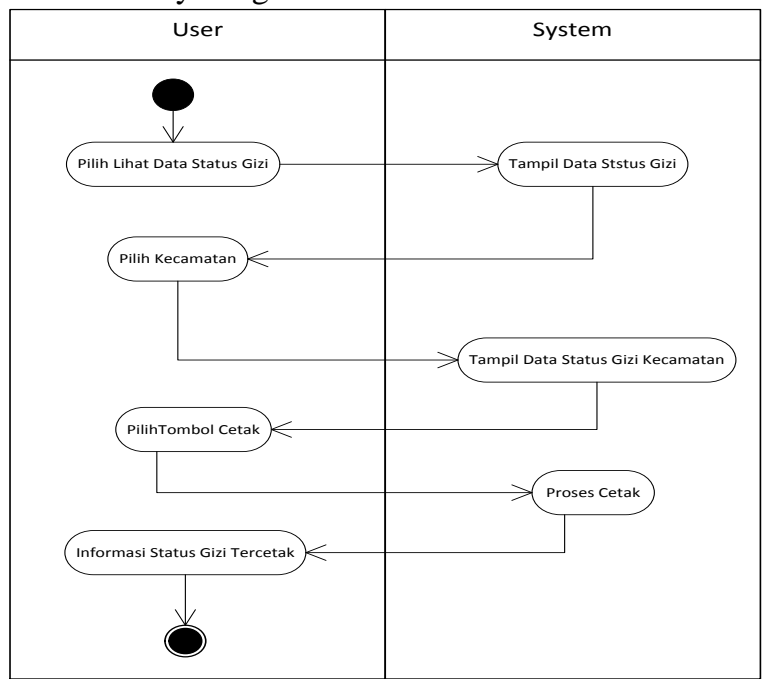

Gambar 8 : Activity Diagram Melihat Data Status Gizi

\section{c. Class Diagram}

Class diagram menggambarkan hubungan antar kelas dalam sistem yang sedang dibangun dan bagaimana mereka saling berkolaborasi untuk mencapai suatu tujuan. Adapun class yang dibutuhkan dalam SIG Pemetaan Gizi Buruk Kota Semarang adalah:

1. Class Kecamatan

2. Class Gizi Kelurahan

3. Class Administrator

Dari class yang telah terbentuk di atas, dapat digambarkan ke dalam bentuk diagram. Berikut adalah class diagram yang terbentuk :

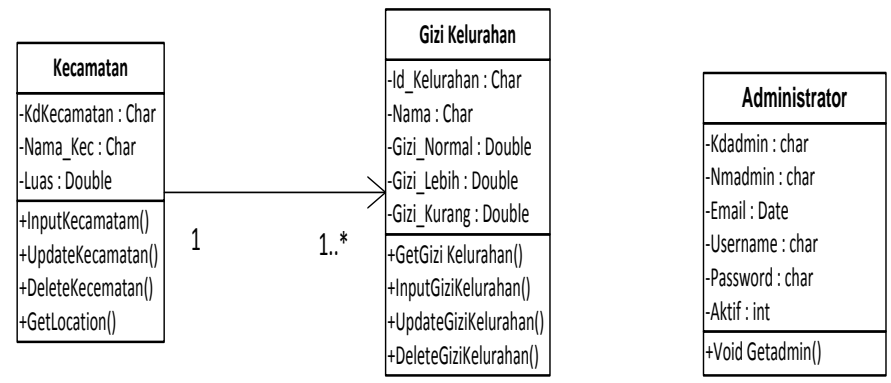

Gambar 9: Class Diagram

Sebagaimana yang terlihat dalam Gambar diatas Composition atau Komposisi Relasi ini merupakan relasi yang paling kuat dibandingkan dengan asosiasi dan aggregasi. Pada komposisi diartikan bahwa suatu kelas merupakan bagian yang wajib dari kelas yang lain. Relasi Kecamatan terdapat banyak Kelurahan.

\section{Desain Tampilan Antarmuka (Interface)}

a. Desain Tampilan Antarmuka (Interface) Dashboard Admin

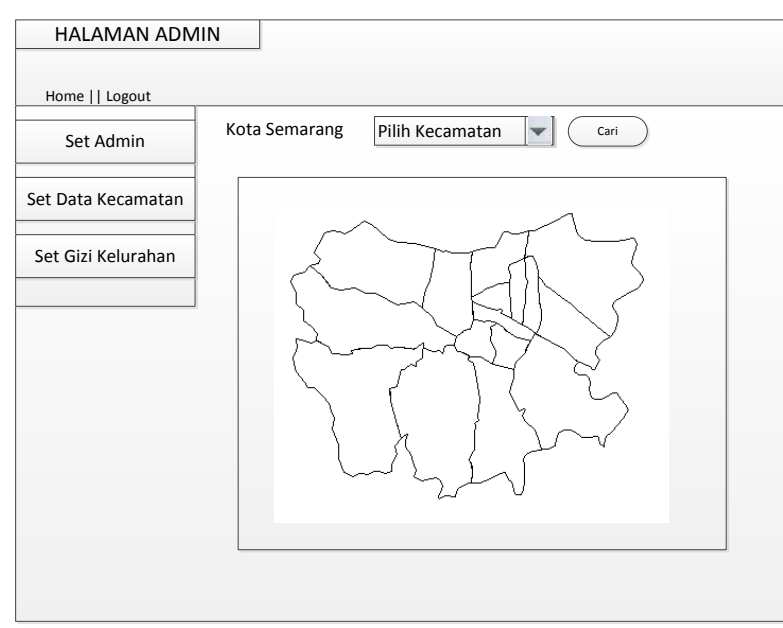

Gambar10: Desain Interface Dashboard Admin

b. Desain Tampilan Set Data Kecamatan

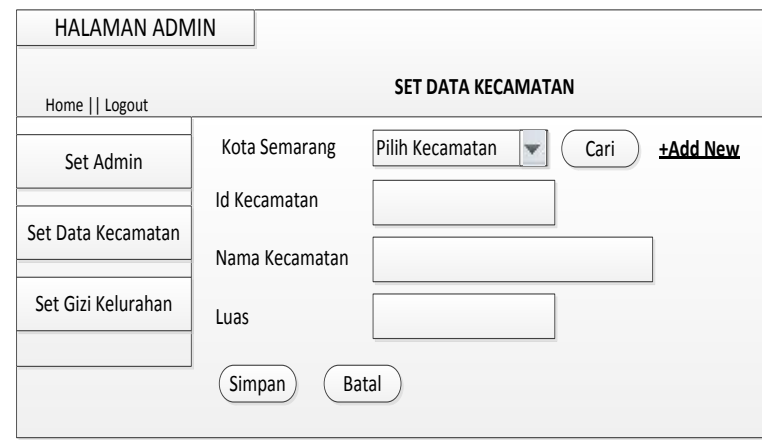

Gambar11: Desain Interface Set Data Kecamatan

c. Desain Tampilan Set Data Gizi Kelurahan 


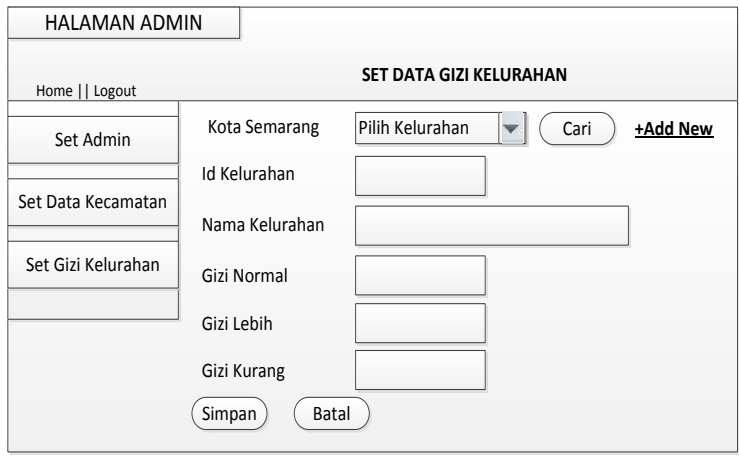

Gambar12: Desain Interface Set Data Kelurahan

d. Desain Tampilan Lihat Status Gizi
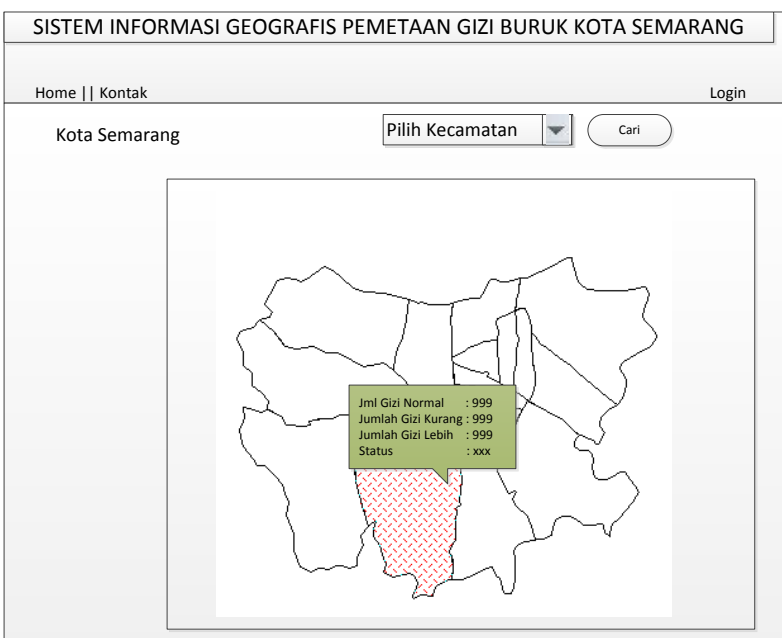

Gambar13: Desain Interface Set Data Kelurahan

IV. IMPLEMENTASI

a. Form Set Data Kecamatan

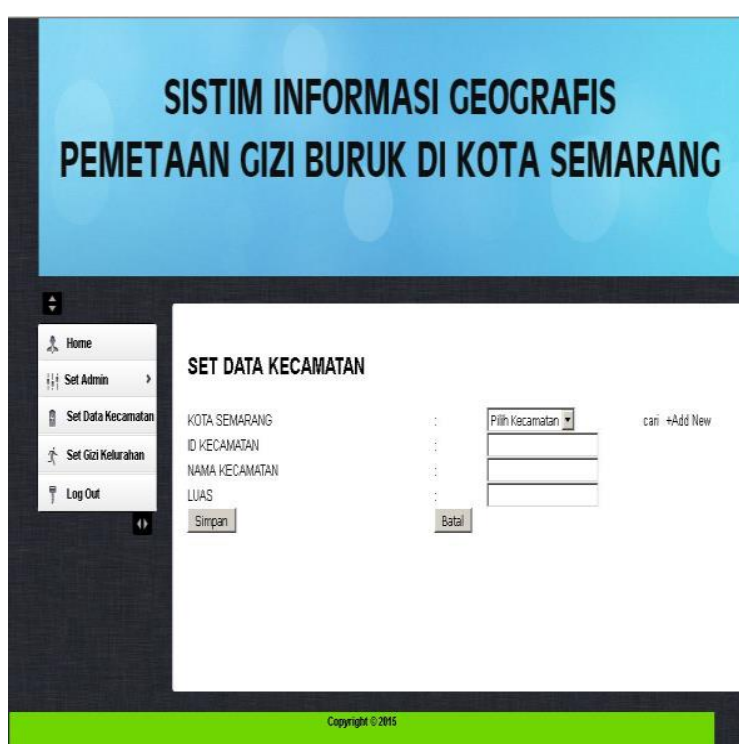

Gambar15: Form Set Data Kelurahan b. Tampilan Lihat Status Gizi

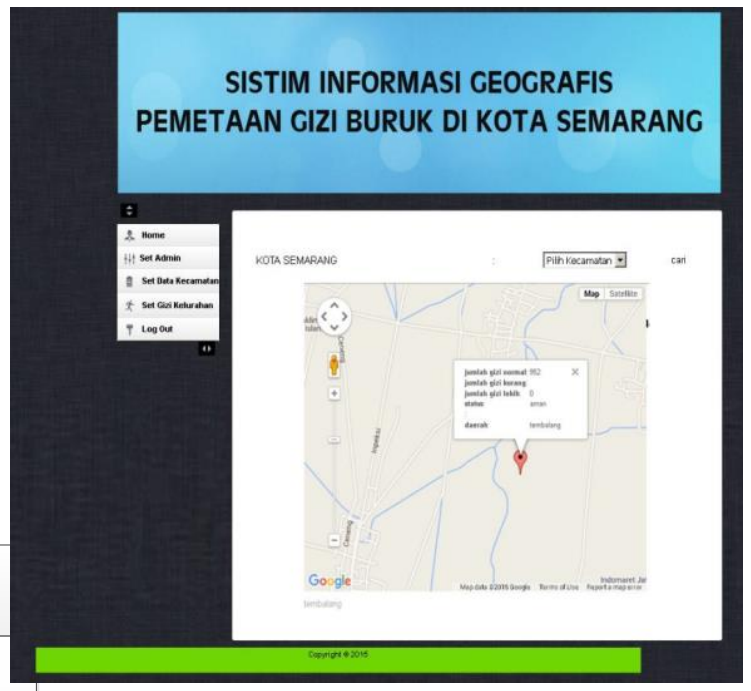

Gambar16: Tampilan Lihat Status Gizi

\section{PENGUJIAN SISTEM}

Pengujian dilakukan dengan metode white box dan black box, dalam hal ini pengujian white box dilakukan dengan menguji kompleksitas siklomatis dari sistem dan pengujian black box dilakukan untuk menguji input dan output yang dihasilkan. Adapun hasil pengujian black box dengan menguji combo box pencarian kecamatan, hasil pengujian menunjukkan Pencarian data kecamatan berhasil dilakukan. Hal ini terlihat bahwa kecamatan yang dicari di blok dengan warna yang berbeda dan muncul informasi status gizi yang menyertainya.

\section{KESIMPULAN}

Sistem Informasi Geografis pemetaan Gizi Buruk Kota Semarang dapat menjadi salah satu solusi untuk melaporkan dan merangkum data-data gizi yang ada sehingga membantu untuk proses analisis penyebab gizi buruk di suatu wilayah. Desain sistem ini dapat dijadikan sebagai rujukan pada dinas atau lembaga terkait dalam upaya menurunkan angka kejadian gizi kurang dan gizi buruk pada balita yang belum mencapai target yang diharapkan dalam Rencana Pembangunan.

\section{DAFTAR PUSTAKA}

[1] T. Penyusun, "Profil Rumah Gizi Kota Semarang”, 2014.

[2] E. Prahasta, "Konsep Dasar Sistem Informasi Geografis”, Bandung: CV. Informatika, 201.

[3] W. Adisasmito, "Sistem Kesehatan”, Jakarta: :Rajagrafindo Persada, 2010.

[4] S. Rosa AS, "Rekayasa Perangkat Lunak Terstruktur dan Beriorentasi Objek", Informatika : Bandung, 2014. 